\title{
Abnormal haemoglobin electrophoresis caused by BW 12C
}

\author{
F van Rhee, I Ware, T Littlewood
}

\begin{abstract}
BW 12C, a substituted benzaldehyde, stabilises haemoglobin in the oxy-conformation and has attracted interest as an anti-sickling agent. The drug causes a left shift in the oxygen saturation curve and may induce tumour anoxia and enhance the effect of cytotoxic drugs. During clinical trials in patients with cancer abnormal bands on haemoglobin electrophoretic strips were observed. This made correct diagnosis of abnormal haemoglobins impossible. Solubility tests for sickling disorders (Itano) also proved unreliable.
\end{abstract}

(F Clin Pathol 1992;45:930)

BW $12 \mathrm{C}$ is a substituted benzaldehyde which causes a dose dependent left shift in the oxygen saturation curve by binding to oxyhaemoglobin. ${ }^{1}$ The drug inhibits sickling by increasing red cell oxyhaemoglobin and reducing the polymerisation of dexoyhaemoglobin. It was initially designed to treat the crises of sickle cell anaemia. ${ }^{2} \mathrm{BW} 12 \mathrm{C}$ induces tumour anoxia and necrosis by reducing peripheral oxygen delivery, and is currently being evaluated in clinical trials for its anti-neoplastic activity. BW 12C may synergise with and enhance the cytotoxic effects of chemotherapeutic agents such as mitomycin $C$ which are selectively toxic towards hypoxic or anoxic cells.

\section{Heemoglobin electrophoreais} pH 8.9. (TRISHEDTABorew butier)

Department of Haematology, John Radcliffe Hospital, Headington, Oxford OX3 9DU

$\mathrm{F}$ van Rhee

I Ware

T Littlewood

Correspondence to:

Dr van Rhee

Accepted for publication 23 March 1992

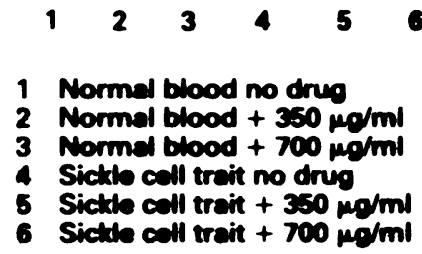

Haemoglobin electrophoresis of normal and sickle cell trait blood after incubation with BW $12 C$

\section{Case report}

An abnormal band was observed during haemoglobin electrophoresis in a 62 year old Chinese man who was receiving treatment with BW 12C and mitomycin C for metastatic adenocarcinoma. His red cell indices suggested thalassaemia trait, and haemoglobin electrophoresis on cellulose acetate at $\mathrm{pH} 8.9$ showed a fast moving band relative to the $\mathrm{HbA}$ position. Haemoglobin electrophoresis on citrate agar at $\mathrm{pH} 6.2$ was unaffected. When haemoglobin electrophoresis was repeated one day later the abnormal band had disappeared. In published studies with healthy volunteers no clinically relevant effect of BW $12 \mathrm{C}$ on the oxygen saturation curve could be shown after 24 hours and the elimination half life was estimated to be 8.4 hours. ${ }^{3}$

The abnormal band could be reproduced in vitro by incubating lysates of red cells with therapeutic doses of $\mathrm{BW} 12 \mathrm{C}$, indicating that BW 12C rather than an active metabolite was responsible for the observed effect (figure). When red cells of patients with structural variants such as sickle cell trait, $\mathrm{Hb} \mathrm{C}$ trait, and $\mathrm{Hb} S \mathrm{C}$ disease were studied, additional bands were noted after incubation with BW $12 \mathrm{C}$, making correct interpretation of the results impossible. In homozygous sickle cell anaemia an additional band close to the $\mathrm{HbA}$ position was observed.

Routine screening tests (sickle cell preparations and Itano solubility tests) for sickling disorders gave false negative results after BW $12 \mathrm{C}$ in heterozygous conditions such as sickle cell trait; in homozygous sickle cell anaemia only low grade positive reactions were recorded. By stabilising sickle cell haemoglobin in the oxy-conformation $\mathrm{BW} 12 \mathrm{C}$ protected against the formation of insoluble deoxyhaemoglobin induced by reducing agents (metabisulphite and dithionite) used in screening tests.

Accurate diagnosis of thalassaemic disorders was difficult because the mobility of the haemoglobin A2 band was also altered significantly. Haemoglobin $F$ as measured by the Betke alkali denaturation method was not affected.

1 Beddell CR, Goodford PJ, Nein J, White RD, Wilkinson S, Wootton $R$. Substituted benzaldehydes designed to increase the oxygen affinity of human haemoglobin and inhibit the sickling of sickle erythrocytes. $\mathrm{Br} \mathcal{J}$ Pharmacol 1984;82:397-407.

2 Keidan AJ, White RD, Hvehns ER, et al. Effect of BW 12C on oxygen affinity of haemoglobin in sickle-cell disease. Lancet 1986;ii:831-4.

3 Fitzharris P, McLean AEM, Sparks RG, et al. The effects in volunteers of $\mathrm{BW} 12 \mathrm{C}$ a compound designed to left-shift the blood oxygen saturation curve. $\mathrm{Br} \mathcal{F}$ Pharmacol 1985;19:471-81. 